\title{
THE ROLE OF SOFT SKILLS IN ENHANCING THE IMPACT OF INTERNAL MARKETING ON CUSTOMER SATISFACTION AN APPLIED STUDY OF A SAMPLE OF PRIVATE BANK MANAGERS IN BAGHDAD
}

\author{
Ahmed Ghazi Mahdi, Prof. Saadoun Hammoud Al-Rabaiwi \\ University of Baghdad / College of Administration and Economics
}

DOI: $10.37648 /$ ijrssh.v10i02.023

Received: $30^{\text {th }}$ March, 2020; Accepted: 20 ${ }^{\text {th }}$ April, 2020; Published: 07 $7^{\text {th }}$ May,2020

\section{ABSTRACT}

This study examined the effect of elements of internal marketing activities on customer satisfaction through an exploratory study of banking services in Baghdad City. This study aims to determine the effect of internal communication, training and internal market research on customer satisfaction, represented by quality of service, loyalty and market share. And the role that soft skills play in strengthening this relationship, as the research attempted to provide a comprehensive theoretical framework for the most important presented by the book and researchers on the variables of research, data was collected using a questionnaire-based survey consisting of 36 questions and distributed to (223) managers of private banks in the city of Baghdad. The research attempts to answer a set of questions. The body of the research problem (is there a correlation and influence between the dimensions of internal marketing and customer satisfaction, and between soft skills and customer satisfaction, do soft skills reinforce positively and morally the relationship between internal marketing and customer satisfaction), in order to analyze the data that has been Obtained from questionnaires, quantitative methods such as mean, standard deviation, coefficient of variation, simple correlation coefficient, and structured equation modeling were used. The results showed that the elements of internal marketing activities have a major impact on customer satisfaction. Finally, the study recommends that management should improve internal marketing activities by applying the activities appropriate to the company's business to obtain customer satisfaction

Keywords: internal marketing, soft skills, customer satisfaction

\section{INTRODUCTION}

All businesses, especially telecom companies, have been affected to some extent by what is happening in the global market. Now companies are not only aiming to satisfy customers but they are trying to do it more efficiently and effectively than their competitors in the competitive market in order to achieve their goals. The most important goal of the company is to maintain customer satisfaction and focus on a customer-centric approach in their organizational and marketing strategies, as it is necessary to place the customer in the business center according to his strategies, events and operations. In fact it is easier and more profitable to sell to existing customers than to find new customers. Therefore, the telecommunications company develops its strategies to ensure customer satisfaction and retention, and therefore its employees must be more customerfocused, 
On the part of the organization, this is done through the adoption of a set of marketing activities and programs, which are internal marketing, which in turn focuses on employees and considers them internal customers of the bank, so the interest that starts from within and the knowledge of the needs and desires of workers is the result of which is reflected in the bank's performance and the services provided to customers, so Internal communication is considered one of the most important elements of internal marketing activities, whether these communications are horizontal between employees or vertical between the top management and the bank's departments remained, and it is not possible to deny the training component in crystallizing the internal marketing activities in the bank, as the availability of land The training and development field for workers consists of a set of skills and capabilities represented by soft skills that can be benefited from as a result of the rapid developments in the banking industry. The internal market research is considered an important pillar of the internal marketing if knowing the needs and requirements of the internal customer is like a spark to be acquainted with the ideas, desires and possession of external customers and how to satisfy and retain them.

So this research was divided into four main sections, the first section represented by the research methodology, and the second section came to clarify the theoretical aspect of the research, while the third section came to explain the practical and analytical aspect of the research, and finally the research concluded with a set of conclusions reached by the research and recommendations

\section{THE FIRST TOPIC: RESEARCH METHODOLOGY}

\section{First: The research problem and its questions}

As a result of the complexity and continuous change that characterize the business environment in our time, as a result of many factors, the most important of which are rapid developments in the field of technology, especially in the field of banking industries, as well as the practices and activities that workers inside the bank carry out to achieve goals and excellence in performance from other banks, In addition to the obstacles and problems that the company faces from adopting or applying a new idea and the possibility of merging it with current ideas due to the lack of skills and capabilities due to the companies 'lack of continuous training and development of workers, in addition to the companies' inability to analyze and understand Employees and knowing their needs and desires so that they can provide the best services that are reflected in the performance of the company.

This research attempts to reveal the nature of the relationship between internal marketing and customer satisfaction, as it also attempts to focus on the soft skills of managers as an interactive variable that enhances this relationship. Organizations that have their own soft skills contain creative and intellectual capabilities that can be a competitive advantage for these organizations and as a result can Compete with competing organizations in the same industry.

The topic of customer satisfaction is one of the vital topics that many writers and researchers in the field of marketing have focused on because it has an important role in proposing new ideas and methods that pertain to customers and that helps companies to provide excellent services that meet the needs and desires of customers and thus the ability to reach their satisfaction with the service provided. The application of internal marketing activities and programs to ensure access to customer satisfaction by mediating soft skills in private banks is a problem in itself, and therefore the current research problem can be formulated through the following questions:

1- $\quad$ Are internal marketing activities and programs available in the researched company?

2- $\quad$-Are soft skills programs and activities available in the researched banks, and what is the level of those skills with them?

3- -What is the level of customer satisfaction in the research banks?

4- $\quad$-Is there a correlation and influence between internal marketing dimensions and customer satisfaction, and between soft skills and customer satisfaction?

5- $\quad$-Do soft skills positively and morally enhance the relationship between internal marketing and customer satisfaction?.

\section{Second: The importance of research}

The importance of the current research is evidenced by the following points:

1-The current research contributes to directing the attention of managers in Iraqi private banks, the sample of research towards internal marketing activities, soft skills and customer satisfaction, as it is a modern management concept.

2-Research topics (internal marketing, soft skills, customer satisfaction) are important and worthy of attention, due to the lack of Arab studies that combined the three topics according to researchers' knowledge, so there are few percentages of Arab 
studies that dealt with research in the nature of the relationship between internal marketing The customer is satisfied with soft skills

3-Business companies are trying in our time to implement internal marketing activities and programs as a pillar of corporate success, because internal marketing helps companies to stimulate training and development for their workers in a way that can be distinguished by their performance and thus obtain satisfaction for their customers.

4-The importance of the current research can be framed through the sector that was highlighted, which is the banking industries sector, as it has an important role in the lives of the general public, and constitutes a basic pillar in the service sector in a manner that enhances customer satisfaction in these banks

\section{Third: Research objectives}

The research objectives can be embodied in the following points:

1-Diagnosing internal marketing activities and customer satisfaction in the research banks?

2-To reveal the extent of the influence of soft skills in enhancing the relationship between internal marketing and customer satisfaction.

3-Determining the strength and direction of the relationship between internal marketing and customer satisfaction, soft skills and customer satisfaction.

4-Diagnosing the relationship between the effect of internal marketing activities on customer satisfaction.

5-Disclosing the interactive role of soft skills in enhancing the impact of internal marketing on customer satisfaction

\section{Fourth: The hypothesis of the research}

As a result of what was presented in the research problem and its importance and basic goals, a hypothetical structure was formulated and designed in Figure 1, which expresses the nature and type of basic and subsidiary relationships between research variables.

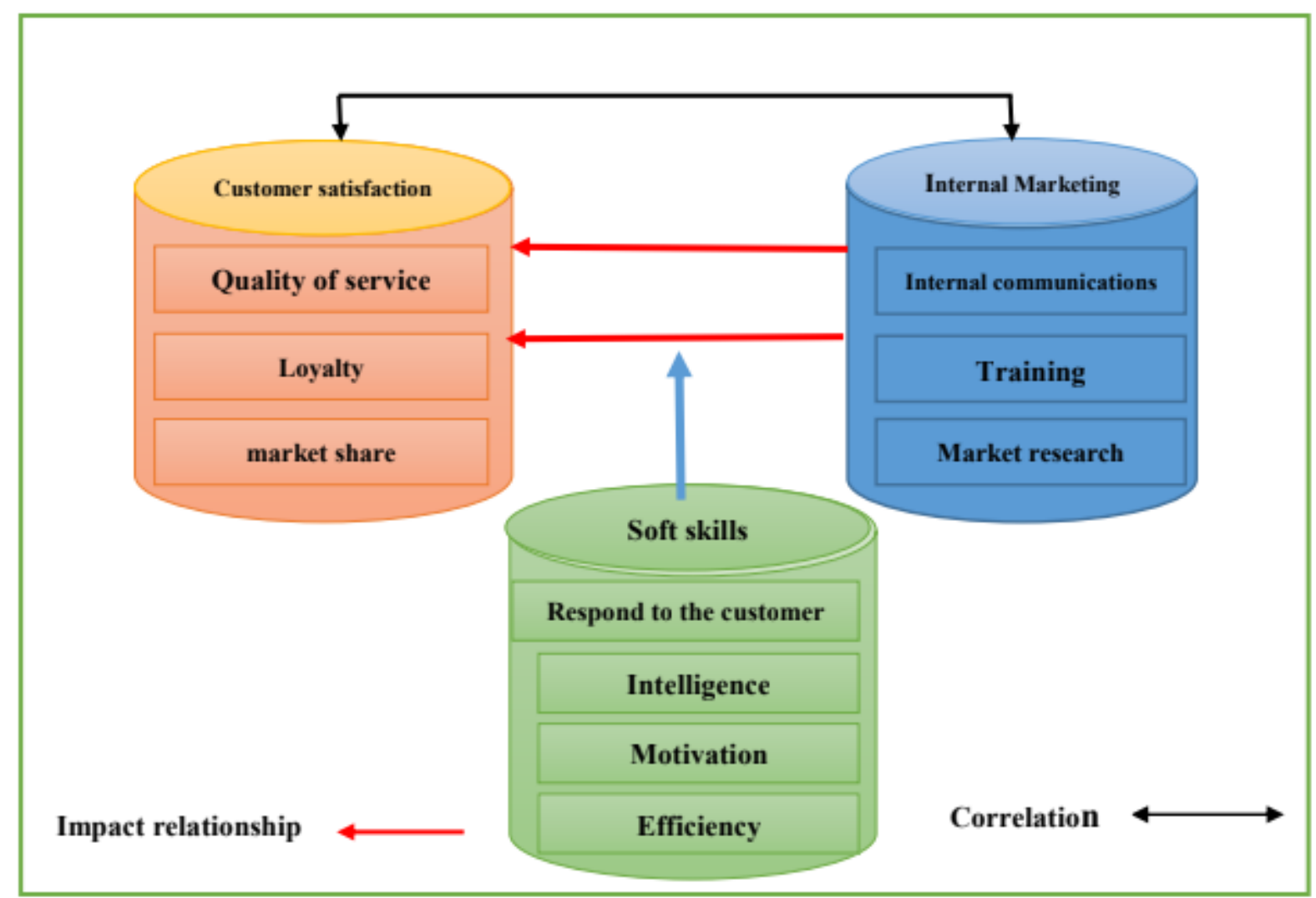

Figure (1) research model

\section{Fifth: research hypotheses}

\section{1-Correlation hypotheses}

-The first main hypothesis: There is a significant correlation between internal marketing and soft skills, and three subhypotheses are branched from it as follows: 
-The first sub-hypothesis: There is a significant correlation between internal communication and soft skills.

-The second sub-hypothesis: There is a significant correlation between training and soft skills.

-The third sub-hypothesis: There is a significant correlation between internal market research and soft skills.

-The second main hypothesis: There is a significant correlation relationship between soft skills and customer satisfaction, and four sub-hypotheses are branched out as follows:

-The first sub-hypothesis: There is a significant correlation between customer response and customer satisfaction.

-The second sub-hypothesis: There is a significant correlation between intelligence and customer satisfaction.

-The third sub-hypothesis: There is a significant correlation between motivation and customer satisfaction.

-Fourth sub-hypothesis: There is a significant correlation between efficiency and customer satisfaction.

\section{2-Impact hypotheses}

-The third main hypothesis: There is a statistically significant effect of internal marketing on customer satisfaction, and three sub-hypotheses are branched out as follows:

-The first sub hypothesis: There is a statistically significant effect correlation of internal communication in the dimensions of customer satisfaction.

-The second sub-hypothesis: There is a statistically significant effect relationship for training in the dimensions of customer satisfaction.

The third sub hypothesis: There is a statistically significant effect of market research on the dimensions of customer satisfaction.

-The fourth main hypothesis: There is an interactive effect of soft skills with internal marketing to influence customer satisfaction, and three sub-hypotheses are branched as follows:

-The first sub-hypothesis: There is a relationship of interactive influence of soft skills with internal communication to influence customer satisfaction.

-The second sub-hypothesis: There is an interaction effect of soft skills with training to influence customer satisfaction.

-The third sub-hypothesis: There is an interactive effect relationship of soft skills with internal market research to influence customer satisfaction.

\section{Sixth: Research community and sample}

The research community consists of (253) managers, divided between managers and heads of departments and what is represented by them in (52) private banks in Baghdad, and the sample of the research was after applying the Richard Jaeger equation (233) managers, the questionnaires were distributed to the survey sample on (18) banks and after Sorting and tabulating questionnaires in the statistical program show that there are (10) non-fulfilling conditions, and therefore the valid questionnaires for analysis (223) are questionnaires.

\section{Seventh: Research Approach:}

When formulating the research, the researcher adopted the descriptive approach in the theoretical aspect as well as analyzing the impact and correlation relationships between the research variables.

Eighth: the limits of research

Spatial limits: The research was limited to Iraqi private banks in Baghdad, as they represent a large segment in the services sector, which deals with the customer with direct contact, and for its cooperation with the researcher and its geographical proximity.

Time limits: The period of completion of the research extended from 12/11/2019 to 3/17/2020.

\section{Ninth: Data collection methods and tools}

The researcher relied on foreign sources in the theoretical aspect of the research, which were books, articles, theses and messages related to the current research topics, as well as the sources on the websites.

As for the practical aspect, the researcher relied on the questionnaire as a main tool and the most consistent with the current research trends, and a five-factor scale (Likert) was used .Table (1) shows the search variables and paragraphs of the measuring instrument. 
Table (1) variables, dimensions and paragraphs of the measuring instrument

\begin{tabular}{|c|c|c|c|c|}
\hline sources & coding & $\begin{array}{l}\text { number of } \\
\text { paragraphs }\end{array}$ & Dimension & variables \\
\hline \multirow{3}{*}{$\begin{array}{l}\text { Huang\& Thiele,2014 } \\
\text { and } \\
\text { Yu-Ting,2015 }\end{array}$} & INCO & 5 & $\begin{array}{c}\text { Internal } \\
\text { communications }\end{array}$ & \multirow{3}{*}{$\begin{array}{c}\text { Internal Marketing } \\
\text { (INMA) }\end{array}$} \\
\hline & TR & 4 & Training & \\
\hline & IMSE & 3 & $\begin{array}{c}\text { Internal market } \\
\text { research }\end{array}$ & \\
\hline \multirow{4}{*}{ Sain\& Wilde,2014 } & CUR & 3 & $\begin{array}{c}\text { Respond to the } \\
\text { customer }\end{array}$ & \multirow{4}{*}{$\begin{array}{r}\text { Soft skills } \\
\text { (S0SK) }\end{array}$} \\
\hline & INT & 3 & Intelligence & \\
\hline & MOT & 3 & Motivation & \\
\hline & EFF & 3 & Efficiency & \\
\hline \multirow{3}{*}{ Tushi,2014 } & SEQ & 5 & Quality of service & \multirow{3}{*}{$\begin{array}{c}\text { Customer satisfaction } \\
\text { (CUSA) }\end{array}$} \\
\hline & LE & 4 & Loyalty & \\
\hline & MAS & 3 & market share & \\
\hline
\end{tabular}

\section{THE SECOND TOPIC: THEORETICAL FRAMEWORK FOR RESEARCH}

\section{First: internal marketing}

1-The concept of internal marketing

The concept of internal marketing focuses on how to build internal relationships through the treatment of employees as the company's first customers at the present time, the concept of internal marketing extended and not limited to marketing services only to become a model for all organizations seeking to achieve a distinct performance (Cătălin, 2014: 10). In the same vein (Tushi, 2014: 14) indicated that the internal marketing interest in how all employees and members of the organizational organization work as one team to achieve the company's goals and objectives, the support and commitment of employees towards the customer is directed. From an administrative perspective, the implementation of internal marketing involves accepting the idea that The internal and external markets of the founder Of similar and can be processed in a manner similar to that it will be dealt with internal marketing as a group of internal and external trade relations. Management needs to use specific methods and procedures to address internal marketing as a process (Kadic-Maglajlic et al, 2017: 2).

)Proctor, 2010: 257) has known internal marketing is the idea of putting employees in the first place in order to obtain organizational purposes. The last internal marketing was known as the philosophy of human resources management to develop jobs as products (Abzari et al, 2011: 148). The board attributes managers to change their management culture by recruiting, training and motivating employees in line with the new vision and a way to build employee satisfaction (Munir et al,2015:358). It is referred to through its relationship to external marketing as it focuses on internal processes through which all employees of the organization ensure an understanding and implementation of appropriate activities and marketing programs, and also ensures that external marketing performs properly and appropriately (Friberg, 2015).

Based on the foregoing, internal marketing can be defined, "it is a directed effort aimed at removing barriers between departments and achieving strategic alignment between employees who influence customers and marketing activities".

2-The importance of internal marketing

The importance of internal marketing can be embodied by describing the performance of employees and other administrative members by working as a team to achieve the goals and objectives of the organization. Therefore, the commitment and support of workers towards the customer guarantees an effective market strategy. Therefore, the internal marketing of the organization must be comprehensive and start heading towards the market by adopting an organizational culture, as the workers work as a team and are constantly committed to creating superior customer value, or a package. Among the marketing activities that guarantee to improve the performance of the organization (Tasmia, 2014: 9). Internal marketing represents an approach that seeks to serve the management of organizations, as this approach supports and stimulates all 
members of the organization, and works to study what their roles and results are, and the possibility of adopting a degree of awareness In customer orientation, it also focuses on achieving customer satisfaction The quality and effectiveness of organizational productivity through continuous improvement in employee performance and their environment (Farouk et al, 2010: 1197) It is successful organizations that develop internal and external marketing in a balanced and equal way, as it is not possible to expect good performance from the organization and its employees are not ready To present, therefore, the successful application of the principles of internal marketing in the internal market for work is a prerequisite for the effectiveness of external marketing (Lombard, 2010: 371).

3-The dimensions of internal marketing

Many studies, research and literature have met on the existence of three marketing activities that represent the main types of internal marketing, and include internal communications, training, market research

A- Internal Communications: Internal communications are the most common dimension of internal marketing. Many scientists drew attention to the impact of communication on employee development, either by changing employee attitudes or increasing customer satisfaction (Yu-Ting, 2015: 4). (Tourani\&Rsat, 2012: 36) concluded that internal communication is a new contract between the employer and employee Between managers and employees The "employer-employee relationship" may require managers to rethink their role and learn about the processes by which value is created profitably for employees.

B- Training: Much research has examined the conceptual foundations of the training component in internal marketing, which can be divided into four main categories: service standards, training, development and rewards programs (Papasolomou\&Vrontis, 2006: 181). Another indicated that workers are the organization's greatest resource, and they need Ongoing development and training to be human capital and they are aware of changes in the environment and provide them with new skills and capabilities to provide quality services in the era of intense competition (Beyerlein et al, 2003: 169.(

C- Internal market research: Market research is an effective tool in any industry for analyzing the types of customers and understanding their needs and desires, internal market research has a similar function while market research is used to analyze and understand employees, if the institutions are not aware of the existence of different types of employees and their needs are different Also, internal market research is an important component of understanding how to implement both a marketing-like HRM approach (Rafiq\& Ahmed, 2003: 452). Market research was initially a simple concept that became more complex over time, as most studies did not seek employee opinions This is a serious omission since employee perceptions are critical to the organization (: Huang \& Thiele, 2014).

\section{Second: soft skills}

1-The concept of soft skills

Riggio highlighted the researchers 'need to focus more on soft skills, noting that compared to studying more alleged technical skills, as it was clarified that researchers had not developed acceptable and directed models for categorizing soft skills (and do not understand where hard skills stop and soft skills begin). Finally, there are many combinations of competencies, abilities, and behaviors that make up the smooth side of leadership. Therefore, there are no comprehensive guidance frameworks for developing these skills (Riggio, 2014: 2). The use of the term "soft skills" can be seen first of all in personnel administrations, in further education, in personnel administration, or in management consulting (Mytzek.el.at, 2004: 24). (Stewart et al, 2016: 646) sees soft skills These are non-technical and practical skills that employees are expected to possess and are often difficult to measure. Soft skills such as communication, problem solving and critical thinking are among the important skills that must be possessed in any industry but are especially important in the global environment. Another defines them as personal characteristics and interpersonal skills in developing and maximizing human action, for example training, team building, decision-making and initiatives (Rasmani\&Wibowo, 2017: 45) As Tulgan (2015: 7) notes, soft skills encompass a wide range of non-technical skills ranging from "self-awareness" to "people's skills" to "problem-solving" to "teamwork".

Based on the definitions above, the researchers agree that soft skills are non-technical skills and do not depend on abstract thinking, including personal and internal capabilities, to facilitate perfected performance in specific contexts.

2-The importance of soft skills

There are many reasons for a critical look at a person's soft skills, and one of the obvious reasons is the job market today, which in many areas is becoming increasingly competitive. To be successful in this challenging environment, job candidates must take advantage of the "competitive advantage" that sets them apart from other candidates with similar qualifications and similar evaluation results. Where do they find this competitive advantage? In bringing in additional knowledge and skills, it was added by convincing personal traits and customs (Schulz, 2008: 149). In a study to determine the quality of project management professionals, it was found that the key to complex project management is soft skills. Fifty percent of the respondents say that people's skills are the most important factor in dealing with the complexity of the project. Less than 25 
per cent feel that the most difficult skills of operation and product knowledge are the most important. "Individuals present successful projects and not only apply methods and tools," he said, and identified the most important soft skills are skills "communication, motivation, delegation, ownership and a sense of achievement" and leadership skills (Levasseur, 2013: 566). According to (Bowden.et.al, 2000: 131) there are three basic arguments about the importance and inclusion of soft skills for graduates in higher education, all of which relate to the changing role of universities. First, it is now considered the role of universities in the production of citizens, who can be agents of social change and good for society. Second, after graduation, students face an uncertain future and need to prepare for it. Third, employers expect to see a specific set of general capabilities that graduates have demonstrated. Graduates' skills are discussed to be able to provide and fulfill the above assumptions and suggestions.

3-The dimensions of soft skills

Through the review of the literature and studies related to the removal of soft skills, many classifications and types emerged within the context of previous conceptual theoretical studies or (empirical) field studies. The present study relied on the classification of the study (Sain \& Wilde, 2014)) specifically soft personal skills for two reasons:

-This study provided a comprehensive theoretical framework and employed it in a comprehensive case study for clients, and it was tested to reach results that support the current research.

-To classify the types presented by the study to exclude soft skills, reflecting the distinct dimensions of soft skills dimensions among the different types of previous studies.

A-Responding to customers:To respond to customers, organizations must have the basic competencies to form the basis for customer benefits and strong relationships with customers (Griese.et.al,2012:468).Customer Relationship Management requires different competencies, i.e. knowledge and skills. This includes skills to respond to the customer, about, understanding, and anticipating customer needs and desires Customer dealing skills, allocation skills with a specific cost budget, creativity, problem solving and analytical skills. It is important to mention also the ability to create added value for customers and their company, customer information extraction skills, the ability to measure customer loyalty management and skills in building relationships and collaboration Effective learning and knowledge transfer(Liewel at,2008:521).(Chebat\&Slusarczyk,2005:669)Most importantly, companies understand customers 'emotions because most of their behaviors are driven by emotions, where customers can obtain many types of responses, for example, After the service fails, customers can either seek compensation or revenge in order to "restore balance in their relationship with the company.

B- Intelligence:(Christopher\&Tanwar,2012:62) indicated that intelligence (wisdom) is the level of understanding. As with knowledge, as intelligence works internally, when you share our experience with others, the lines of intelligence that need to communicate with more understanding of contexts will be created. Another noted that when the value of knowledge (contextual) knowledge extends through in-depth ideas to the upstream and downstream consequences of applying that knowledge, knowledge will become intelligence. Intelligence is defined, for example, as the ability to properly use knowledge that has a major impact on a company's success and more than just increasing Knowledge sharing (Senapathi, 2011: 87)) Intelligence (wisdom) makes the best use of knowledge to achieve organizational goals and this is the key to organizational survival, and knowledge management methods that neglect wisdom may lead to blind actions without the necessary insight (Walke\& Christenson, 2005: 278).

C-motivation:Although it is defined that all individuals or groups are distinguished by a particular motivation, the definition of motivation is not at all easy. (American authors) (Robbins \& Coulter, 2005: 90) explained that motivation is the desire to make great efforts to achieve organizational goals, and this willingness assumes that by meeting the needs of the individual Simultaneously, there are three important elements in this field: effort, organization goals and needs. In his study Nonaka \&vonKrogh, 2009: 635) these research findings were supplemented by finding that punishment / rewards and employee motivation are critical factors in efficient business management. They noted behavioral patterns that have a major impact on the desire to share knowledge, and the soft skill identified "motivation" as a key factor in the transfer of knowledge (Foss et al, 2010: 455).

According to Foss.et.al, 2009:874), three types of drivers can be distinguished: internal, external, and advanced motivation. These different types of motivation depend on individual characteristics and may lead to different characteristics in the performance of work and include different environments between people, of course , Each type of motivation also has an impact on employee knowledge sharing behavior.

D- Efficiency: Understanding employee competencies helps to properly address the development of competencies, and there are many other definitions of competencies by scientists, however, scientists largely agree that competency is a distinct group of the individual of knowledge, skills, and motivation to perform the function of (Moore.et.al,2002:1314)).Several authors 
have suggested more or less comparability as competencies are categorized into five groups related to sustainability or corporate social responsibility (Ploumetal,2017:11)providing an approved framework with six specialties:

1-Strategic efficiency of management and work efficiency: ability to collectively design projects and implement interventions, transfers and strategies for sustainable development practices and the ability to actively engage oneself in irresponsible actions to improve the sustainability of social and economic systems.

2-Multidisciplinary competencies: the ability to structure relationships, identify issues, and recognize the legitimacy of other perspectives in business decision-making processes, whether it is for environmental, social, or economic issues.

3-Standard competency: The ability to set, apply and reconcile the values, principles and goals of sustainability with internal and external stakeholders without incubating any input, but based on the good character of the person involved in sustainability issues.

4-Incomplete thinking about the future vision: the possibility of collectively analyzing "images", evaluating them and formulating them for the future in which consideration is given to the impact of local or short-term decisions on environmental, social and economic issues. On a global / global scale and in the long run.

5-Personal competence: the ability to stimulate, enable and facilitate sustainability, collaborative collaborative research and research.

\section{Third: customer satisfaction}

1-The concept of customer satisfaction

Customer satisfaction has a positive impact on the profitability of the organization, and satisfied customers are the basis for any successful business, and customer satisfaction with the products provided, whether it is a service or a commodity, leads to a re-purchase process and high satisfaction leads to loyalty (Hoyer \& MacInni,2017:72). (Feinberg et al,2000: 32) see that a set of factors that affect customer satisfaction are the average response speed, customer waiting time, customer abandonment rate, average work time and service levels. (Souca, 2014:76) Customer satisfaction is an emotional response A summary based on a cognitive assessment that has variable intensity and can be the central satisfaction point at the moment of selection or examination It is not based on or consuming the product or service. The term customer satisfaction can be defined as a marketing term that measures how the products or services provided by the company meet or exceed customer expectations (Blessing \& Natter, 2019:48).It also indicates (Chicu el at,2019:88)that satisfaction is the number of customers or the percentage of the total customers who exceed their reported needs with a company or its products or services. Also known is a feeling of joy or disappointment that results from comparing the organization's expected performance in terms of products or results to the expectations of others (Emaluta el at, 2019: 61).

Based on the above definitions, the researchers agree that customer satisfaction is an emotional state that a customer can obtain when matching his expectations for the services provided with the actual performance of the organization.

2-The importance of customer satisfaction

Customer satisfaction is very important in today's business world, according to Khedkar, 2015: 3)The ability of the service provider to create a high degree of satisfaction is critical to product differentiation and the development of a strong relationship with customers, and customer satisfaction makes them loyal to the service provider. Anderson el at, 20004: 174) Although creating satisfied and loyal customers is costly, this may be profitable for the long term for the company. Therefore, the company must focus on improving the quality of service and imposing an appropriate fair price to satisfy its customers, which ultimately helps the company retain its customers. And companies that succeed in competitive market environments are those that make customer satisfaction a key component of their business strategy. Firms that provide amazing customer experiences create high environments where satisfaction is high and customer defense is highly motivated (Zakaria,2014:104)

3-The dimensions of customer satisfaction

There are a lot of studies and research that have a difficult interface in measuring customer satisfaction and were limited to the single scale, but in the current research, the researchers agree with the study (Tushi, 2014) by specifying (quality of service, customer loyalty, and market share) as dimensions of customer satisfaction as follows:

A- Quality of Service: According to (Lupioyadi, 2008:175),it is a factor in determining the success and quality of the company as the company's ability to provide high-quality service to consumers and a strategy to defend themselves and achieve success in the face of competition. Service organizations began focusing on customer perceptions of quality of service because they help in developing strategies that lead to customer satisfaction (Saravanan\&Rao,2007:199)and (Linnell,2009:233)defined quality of service as the difference between a customer's expectation of service outputs for service inputs and the perception of service received. Therefore, customer expectations serve as a basis for service evaluation. 
B- Customer loyalty:(Kotler\& Keller,2006:43) explains that loyalty is an obligation to buy or support a product that the customer prefers, even though the marketing situation and the company's effort may lead to customers choosing other products, and they argue that customer loyalty can be seen through these three factors Like recommending others to purchase a specific product and then recommending it again to others (orally), refusing to use another product, or showing denial of other products (rejecting another product) and buying the product repeatedly (repurchase). Customer loyalty can be defined as a mixture of tangible and intangible factors that are received when a customer consumes a specific product or service (Agyei\&kilika,2013:27).

It was also known as a deep and deep commitment to continuously buying or selecting a good or service and its preference, as we find that this definition has been focused on the behavioral side despite the marketing efforts and situational influences that have the power to transform customer behavior (Boohene\& Agyapong, 2011: 230).

C- Market share: the market share reflects the efficiency and effectiveness of the organization and the amount of its marketing activity, which reflects its impact on the amount of sales in the market compared to the total sales of the same industry. It fits the products provided by (Clark,1999:15)The market share of the organization represents one of the important indicators that enhance its competitive advantage and that the organization seeks to maintain its market share through the provision of high-quality services and a price policy that develops a more active Its marketing and service, and can know the market share, "the collection of consumers who have potential in their similar needs and Rgathm who have the ability and the desire to carry out the exchange in order to satisfy their needs (Kotler, 2000: 696).

\section{THE THIRD TOPIC: ANALYTICAL ASPECT AND TESTING OF RESEARCH HYPOTHESES}

\section{First: test the normal distribution of the drawn data}

Before starting analyzing the research data and extracting the results that support the theoretical aspect of the research, these data must be subjected to tests for natural distributions, in order for the researcher to know which tests are appropriate for the drawn data, so it will be tested using the Klomkruf-Siminrove and the Chapiro-Willik tests, as their results can be interpreted based on The value of ( $\mathrm{P}$-value), as it is acceptable with a greater significance $(\mathrm{P} \geq 0.05)$, and Table (2) shows the test of the natural distributions of the data.

When interpreting Table (2), it is clear that the results are identical to the imposed rule for the normal distribution, as all the apparent results of the value of P-value) are greater than 0.05 and for all paragraphs of variables, and this means the results that the researcher will reach can be generalized to society as a whole.

Table (2) the normal distribution of the withdrawn data

\begin{tabular}{|c|c|c|c|c|c|c|c|c|c|}
\hline variable & Kol-smi & $\begin{array}{r}\mathrm{p}- \\
\text { value }\end{array}$ & Sha-wil & $\begin{array}{r}\mathrm{p}- \\
\text { value }\end{array}$ & variable & Kol-smi & $\begin{array}{r}\mathrm{P}- \\
\text { value }\end{array}$ & Sha- & $\mathrm{P}-$ value \\
wil & \\
\hline INCO1 & .312 & $\mathrm{P}>0.05$ & .832 & $\mathrm{P}>0.05$ & SEQ1 & .265 & $\mathrm{P}>0.05$ & .788 & $\mathrm{P}>\mathbf{0 . 0 5}$ \\
\hline INCO2 & .232 & $\mathrm{P}>0.05$ & .643 & $\mathrm{P}>0.05$ & SEQ2 & .265 & $\mathrm{P}>0.05$ & .811 & $\mathrm{P}>\mathbf{0 . 0 5}$ \\
\hline INCO3 & .376 & $\mathrm{P}>0.05$ & .742 & $\mathrm{P}>0.05$ & SEQ3 & .298 & $\mathrm{P}>0.05$ & .824 & $\mathrm{P}>\mathbf{0 . 0 5}$ \\
\hline INCO4 & .297 & $\mathrm{P}>0.05$ & .876 & $\mathrm{P}>0.05$ & SEQ4 & .321 & $\mathrm{P}>0.05$ & .837 & $\mathrm{P}>\mathbf{0 . 0 5}$ \\
\hline INCO5 & .298 & $\mathrm{P}>0.05$ & .855 & $\mathrm{P}>0.05$ & SEQ5 & .345 & $\mathrm{P}>0.05$ & .788 & $\mathrm{P}>\mathbf{0 . 0 5}$ \\
\hline INCO & .123 & $\mathrm{P}>0.05$ & .715 & $\mathrm{P}>0.05$ & SEQ & .276 & $\mathrm{P}>0.05$ & .761 & $\mathrm{P}>0.05$ \\
\hline TR1 & .376 & $\mathrm{P}>0.05$ & .612 & $\mathrm{P}>0.05$ & LE1 & .217 & $\mathrm{P}>0.05$ & .796 & $\mathrm{P}>\mathbf{0 . 0 5}$ \\
\hline TR2 & .177 & $\mathrm{P}>0.05$ & .688 & $\mathrm{P}>0.05$ & LE2 & .276 & $\mathrm{P}>0.05$ & .819 & $\mathrm{P}>\mathbf{0 . 0 5}$ \\
\hline TR3 & .265 & $\mathrm{P}>0.05$ & .641 & $\mathrm{P}>0.05$ & LE3 & .387 & $\mathrm{P}>0.05$ & .854 & $\mathrm{P}>\mathbf{0 . 0 5}$ \\
\hline TR4 & .387 & $\mathrm{P}>0.05$ & .678 & $\mathrm{P}>0.05$ & LE4 & .353 & $\mathrm{P}>0.05$ & .847 & $\mathrm{P}>\mathbf{0 . 0 5}$ \\
\hline TR & .375 & $\mathrm{P}>0.05$ & .711 & $\mathrm{P}>0.05$ & LE & .243 & $\mathrm{P}>0.05$ & .877 & $\mathrm{P}>0.05$ \\
\hline IMSE1 & .437 & $\mathrm{P}>0.05$ & .813 & $\mathrm{P}>0.05$ & MAS1 & .336 & $\mathrm{P}>0.05$ & .867 & $\mathrm{P}>\mathbf{0 . 0 5}$ \\
\hline IMSE2 & .365 & $\mathrm{P}>0.05$ & .854 & $\mathrm{P}>0.05$ & MAS2 & .317 & $\mathrm{P}>0.05$ & .881 & $\mathrm{P}>\mathbf{0 . 0 5}$ \\
\hline IMSE3 & .411 & $\mathrm{P}>0.05$ & .778 & $\mathrm{P}>0.05$ & MAS3 & .361 & $\mathrm{P}>0.05$ & .871 & $\mathrm{P}>\mathbf{0 . 0 5}$ \\
\hline IMSE & .388 & $\mathrm{P}>0.05$ & .853 & $\mathrm{P}>0.05$ & MAS & .367 & $\mathrm{P}>0.05$ & .812 & $\mathrm{P}>0.05$ \\
\hline
\end{tabular}




\begin{tabular}{|c|c|c|c|c|c|c|c|r|r|}
\hline INMA & .133 & $\mathrm{P}>0.05$ & .952 & $\mathrm{P}>0.05$ & CUSA & .167 & $\mathrm{P}>0.05$ & .931 & $\mathrm{P}>0.05$ \\
\hline CUR1 & .298 & $\mathrm{P}>0.05$ & .881 & $\mathrm{P}>0.05$ & MOT1 & .298 & $\mathrm{P}>0.05$ & .796 & $\mathrm{P}>0.05$ \\
\hline CUR2 & .217 & $\mathrm{P}>0.05$ & .837 & $\mathrm{P}>0.05$ & MOT2 & .387 & $\mathrm{P}>0.05$ & .837 & $\mathrm{P}>0.05$ \\
\hline CUR3 & .376 & $\mathrm{P}>0.05$ & .812 & $\mathrm{P}>0.05$ & MOT3 & .376 & $\mathrm{P}>0.05$ & .641 & $\mathrm{P}>0.05$ \\
\hline CUR & .240 & $\mathrm{P}>0.05$ & .641 & $\mathrm{P}>0.05$ & MOT & .167 & $\mathrm{P}>0.05$ & .854 & $\mathrm{P}>0.05$ \\
\hline INT1 & .336 & $\mathrm{P}>0.05$ & .876 & $\mathrm{P}>0.05$ & EFF1 & .321 & $\mathrm{P}>0.05$ & .854 & $\mathrm{P}>0.05$ \\
\hline INT2 & .167 & $\mathrm{P}>0.05$ & .770 & $\mathrm{P}>0.05$ & EFF2 & .298 & $\mathrm{P}>0.05$ & .778 & $\mathrm{P}>0.05$ \\
\hline INT3 & .353 & $\mathrm{P}>0.05$ & .811 & $\mathrm{P}>0.05$ & EFF3 & .217 & $\mathrm{P}>0.05$ & .876 & $\mathrm{P}>0.05$ \\
\hline INT & .276 & $\mathrm{P}>0.05$ & .753 & $\mathrm{P}>0.05$ & EFF & .376 & $\mathrm{P}>0.05$ & .855 & $\mathrm{P}>0.05$ \\
\hline
\end{tabular}

Second: the constructive honesty test for the muring instrument

To ensure the consistency of the research scale and the consistency of its paragraphs, a set of statistical tests related to measuring the stability of the scale must be performed, and the most prominent of these tests is the Alpha Krumbach coefficient test, which assumes that the results are higher than (60\%) in order to be accepted. And Table (3) shows Alpha Krumbach parameter for the variables and dimensions of the current search.

Table (3) Alpha Krumbach coefficients for the variables and dimensions of the research Third: Description and diagnosis of search variables

\begin{tabular}{|c|c|c|c|c|c|}
\hline $\begin{array}{l}\text { Krumbach for } \\
\text { the dimension } \\
\text { Krumbach for } \\
\text { the total search }\end{array}$ & $\begin{array}{c}\text { Krumb } \\
\text { ach for } \\
\text { the } \\
\text { dimens } \\
\text { ion } \\
\end{array}$ & $\begin{array}{c}\text { number of } \\
\text { paragraphs }\end{array}$ & The dimension & $\begin{array}{l}\text { The } \\
\text { Krumbach } \\
\text { variable for } \\
\text { the total } \\
\text { variable }\end{array}$ & variable \\
\hline \multirow{10}{*}{.943} & .866 & 5 & $\begin{array}{c}\text { Internal } \\
\text { communications }\end{array}$ & \multirow{3}{*}{.932} & \multirow[t]{3}{*}{ internal Marketing } \\
\hline & .834 & 4 & Training & & \\
\hline & .792 & 3 & $\begin{array}{c}\text { Internal market } \\
\text { research }\end{array}$ & & \\
\hline & .876 & 3 & $\begin{array}{c}\text { Respond to the } \\
\text { customer }\end{array}$ & \multirow{4}{*}{.951} & \multirow{4}{*}{ Soft skills } \\
\hline & .754 & 3 & Intelligence & & \\
\hline & .836 & 3 & Motivation & & \\
\hline & .856 & 3 & Efficiency & & \\
\hline & .813 & 5 & Quality of service & \multirow{3}{*}{.984} & \multirow{3}{*}{$\begin{array}{c}\text { Customer } \\
\text { satisfaction }\end{array}$} \\
\hline & .886 & 4 & Loyalty & & \\
\hline & .827 & 3 & market share & & \\
\hline
\end{tabular}

Third: Description and diagnosis of search variables

1-Description and diagnosis of the internal marketing variable

The results of Table (4) explain that the mean of the internal marketing variable (INMA) reached (3.71), with a standard deviation of power (0.656), a coefficient of variance (0.18), a high level of answers, and a relative importance of $(74 \%)$, and these results explain that the sample survey applied Internal marketing activities with a high rate. As shown in Table (4), after internal market research (IMSE) came first with an average of (4.06), with a standard deviation of capacity (0.502), a coefficient of difference (0.12), a high level of answers, and a relative importance of ( $81 \%)$, and these results explain that the survey sample applies internal market research activities at a high rate, while it happened after training (TR) and after internal communication (INCO) on the second and third ranks in a row with an arithmetic mean of $(3.52,3.56)$ respectively and with a standard deviation of power $(0.738$ and 0.80$)$ respectively and a coefficient of variance $(0.21,0.23)$ respectively and a high level of answers, and with a relative importance of $(70 \%, 71 \%)$, respectively, and these results explain that the respondents applied training activities and internal communications at a high rate.

2-Description and diagnosis of soft skills variable 
The results of Table (5) explain that the mean of the soft skill variable (SOSK) reached (3.52), with a standard deviation of power (0.657), a coefficient of variation (0.18) and a high level of answers, and with a relative importance of (83\%), and these results explain that the research sample applied Soft skills activities with a high rate. As shown in Table (5), after the motives (MOT) came first with an average of (4.12), with a standard deviation of capacity (0.657), a coefficient of variation (0.15), a high level of answers, and a relative importance of (79\%) These results explain that the applied sample has a high concentration of employee motivation, while it was after efficiency (EFF) and after intelligence (INT) and after response The customer (CUR) on the second, third and fourth ranks, respectively, with an arithmetic mean of $(3.26,3.12,3.76)$ respectively and with a standard deviation of power $(0.543,0.798,0.765)$ respectively and a coefficient of difference $(0.16,0.25,0.20)$ respectively and a high level of answers, And with a relative importance of $(76 \%, 83 \%$ and $75 \%)$, respectively, and these results explain that the research sample focuses on the efficiency and intelligence of workers and the rapid.

3-Description and diagnosis of the customer satisfaction variable

When interpreting the results of Table (6) it turns out that the mean of the customer satisfaction variable (CUSA) was (4.02), with a standard deviation of power (0.567), a coefficient of variation (0.13), a high level of answers, and a relative importance of $(81 \%)$. As can be seen from the table (6) That after the quality of service (SEQ) came first with an arithmetic mean of (3.94) and with a standard deviation of power (0.512) and a coefficient of variation (0.13) and a high level of answers, and a relative importance of (79\%), these results explain that the sample examined focuses on Quality of service at a high rate, while after loyalty (LE) and after market share (MAS), it ranked second and third respectively, with an average of $(4.11,4.02)$ respectively and with a standard deviation $(0.556,0.567)$, respectively, and a coefficient of variation $(0.14$ and 0.15), respectively, and a high level of answers, with a relative importance of $(82 \%, 81 \%)$, respectively, and these results explain that the researched sample focuses on customers and how to obtain its loyalty and accessibility On the largest market share in the field of communications. response of customers at a high rate.

\section{Table (4) Description and diagnosis of variable and internal marketing} dimensions

\begin{tabular}{|c|c|c|c|c|c|c|c|c|c|c|c|}
\hline $\begin{array}{l}\text { Import } \\
\text { ance } \\
\text { order }\end{array}$ & $\begin{array}{l}\text { Relati } \\
\text { ve } \\
\text { impor } \\
\text { tance } \\
\end{array}$ & $\begin{array}{l}\text { Coeffici } \\
\text { ent of } \\
\text { variatio } \\
\text { n }\end{array}$ & $\begin{array}{l}\text { standa } \\
\text { rd } \\
\text { deviat } \\
\text { ion } \\
\end{array}$ & mean & $\begin{array}{l}\text { Paragr } \\
\text { aph } \\
\text { code }\end{array}$ & $\begin{array}{l}\text { Impor } \\
\text { tance } \\
\text { order }\end{array}$ & $\begin{array}{l}\text { Relati } \\
\text { ve } \\
\text { impor } \\
\text { tance } \\
\end{array}$ & $\begin{array}{l}\text { Coeffici } \\
\text { ent of } \\
\text { variatio } \\
\text { n }\end{array}$ & $\begin{array}{l}\text { standar } \\
\text { d } \\
\text { deviatio } \\
\text { n }\end{array}$ & mean & $\begin{array}{l}\text { Paragra } \\
\text { ph code }\end{array}$ \\
\hline first & $80 \%$ & 0.23 & 0.905 & 3.97 & MAS1 & fourth & $78 \%$ & 0.15 & 0.61 & 3.90 & SEQ1 \\
\hline second & $71 \%$ & 0.27 & 0.953 & 3.55 & MAS2 & third & $76 \%$ & 0.14 & 0.543 & 3.80 & SEQ2 \\
\hline third & $62 \%$ & 0.39 & 1.190 & 3.08 & MAS3 & first & $84 \%$ & 0.12 & 0.502 & 4.21 & SEQ3 \\
\hline Third & $85 \%$ & 0.15 & 0.657 & 4.26 & MAS & Fifth & $76 \%$ & 0.19 & 0.728 & 3.77 & SEQ4 \\
\hline$* * * *$ & $81 \%$ & 0.13 & 0.567 & 4.02 & CUSA & second & $81 \%$ & 0.13 & 0.908 & 4.02 & SEQ5 \\
\hline & & & & & & First & $79 \%$ & 0.13 & 0.512 & 3.94 & SEQ \\
\hline & & & & & & first & $81 \%$ & 0.13 & 0.538 & 4.05 & LE1 \\
\hline & & & & & & second & $79 \%$ & 0.14 & 0.572 & 3.95 & LE2 \\
\hline & & & & & & third & $83 \%$ & 0.16 & 0.666 & 4.16 & LE3 \\
\hline & & & & & & fourth & $80 \%$ & 0.20 & 0.801 & 4.01 & LE4 \\
\hline & & & & & & second & $82 \%$ & 0.14 & 0.556 & 4.11 & LE \\
\hline
\end{tabular}


Table (5) Description and diagnosis of variable and excluding soft skills

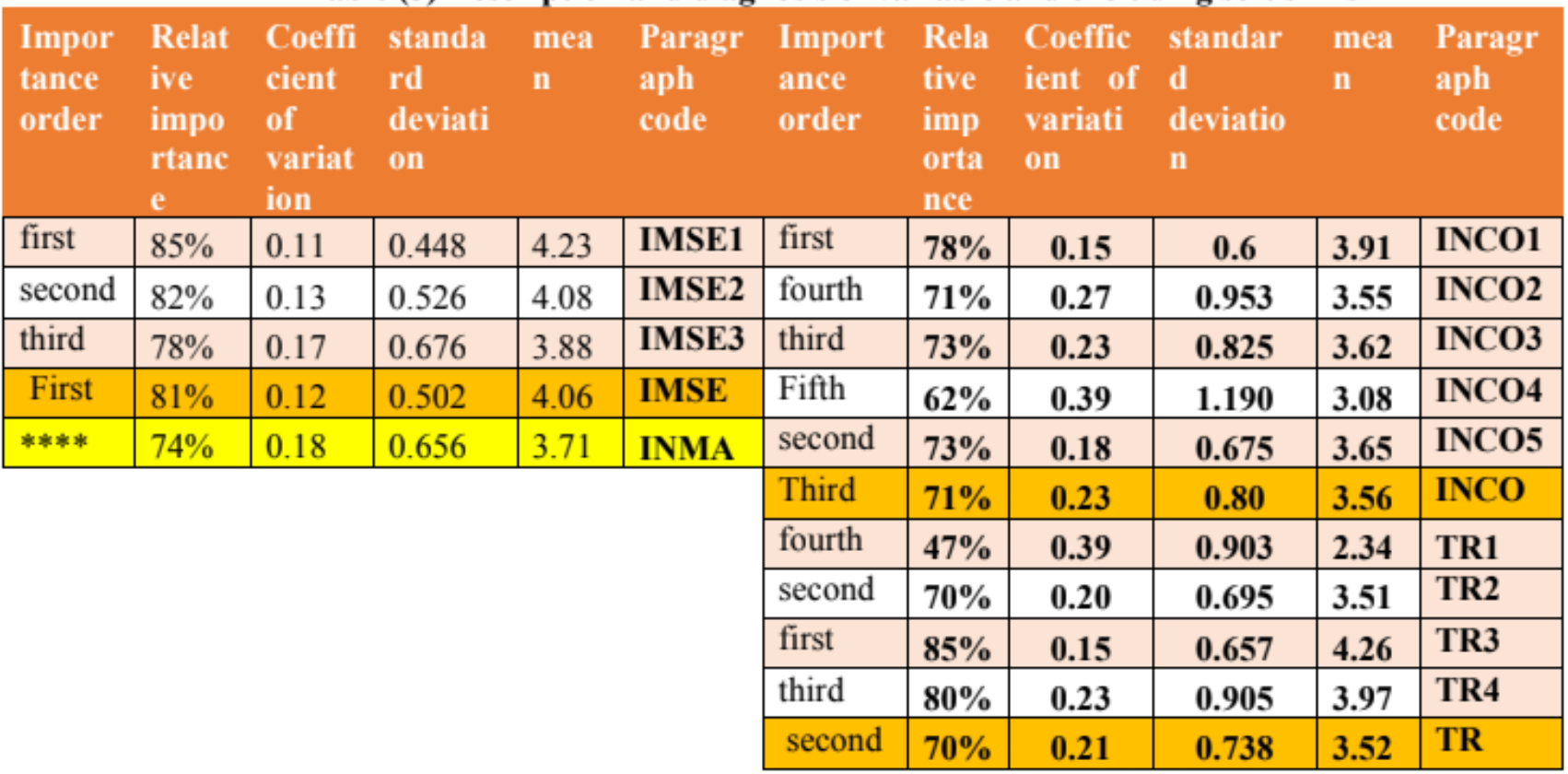

Table (6) Description and diagnosis of variable and customer satisfaction dimensions

\begin{tabular}{|c|c|c|c|c|c|c|c|c|c|c|c|}
\hline $\begin{array}{l}\text { Impor } \\
\text { tance } \\
\text { order }\end{array}$ & $\begin{array}{l}\text { Relati } \\
\text { ve } \\
\text { impor } \\
\text { tance }\end{array}$ & $\begin{array}{l}\text { Coeffic } \\
\text { ient of } \\
\text { variati } \\
\text { on }\end{array}$ & $\begin{array}{l}\text { standard } \\
\text { deviatio } \\
\text { n }\end{array}$ & mean & $\begin{array}{l}\text { Paragra } \\
\text { ph code }\end{array}$ & $\begin{array}{l}\text { Import } \\
\text { ance } \\
\text { order }\end{array}$ & $\begin{array}{l}\text { Relati } \\
\text { ve } \\
\text { impor } \\
\text { tance } \\
\end{array}$ & $\begin{array}{l}\text { Coefficie } \\
\text { nt of } \\
\text { variatio } \\
n\end{array}$ & $\begin{array}{l}\text { standard } \\
\text { deviatio } \\
\text { n }\end{array}$ & mean & $\begin{array}{l}\text { Paragra } \\
\text { ph code }\end{array}$ \\
\hline third & $82 \%$ & 0.28 & 0.905 & 3.17 & MOT1 & second & $71 \%$ & 0.18 & 0.71 & 3.95 & CUR1 \\
\hline second & $78 \%$ & 0.26 & 0.953 & 3.61 & MOT2 & first & $76 \%$ & 0.14 & 0.543 & 3.80 & CUR2 \\
\hline first & $72 \%$ & 0.17 & 0.581 & 3.38 & MOT3 & third & $72 \%$ & 0.22 & 0.712 & 3.21 & CUR3 \\
\hline first & $79 \%$ & 0.15 & 0.657 & 4.12 & MOT & Fourth & $75 \%$ & 0.25 & 0.798 & 3.12 & CUR \\
\hline second & $83 \%$ & 0.16 & 0.622 & 3.74 & EFF1 & third & $73 \%$ & 0.16 & 0.688 & 4.56 & INT1 \\
\hline third & $75 \%$ & 0.18 & 0.594 & 3.28 & EFF2 & second & $64 \%$ & 0.23 & 0.963 & 4.06 & INT2 \\
\hline$t$ first & $71 \%$ & 0.10 & 0.50 & 4.91 & EFF3 & first & $78 \%$ & 0.15 & 0.512 & 3.24 & INT3 \\
\hline second & $76 \%$ & 0.16 & 0.543 & 3.26 & EFF & Third & $73 \%$ & 0.20 & 0.765 & 3.76 & INT \\
\hline & & & & & & 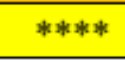 & $83 \%$ & 0.18 & 0.657 & 3.52 & SOSK \\
\hline
\end{tabular}

Fourth: Test the research hypotheses

1-The hypothesis of correlation

Table (7) shows the correlations between research variables represented by internal marketing (INMA) and soft skills (SOSK), so the first main hypothesis and its sub-hypotheses can be explained as follows:

The first main hypothesis: which states (There is a significant correlation between INMA and soft skills (SOSK) 
Table (7) the correlations between internal marketing and soft skills

\begin{tabular}{|c|c|c|c|c|c|c|c|c|c|}
\hline & INCO & TR & IMSE & INMA & CUR & INT & MOT & EFF & SOSK \\
\hline INCO & 1 & & & & & & & & \\
\hline TR & $.915^{\text {kk }}$ & 1 & & & & & & & \\
\hline IMSE & $.945^{k-k}$ & $.867^{k-k}$ & 1 & & & & & & \\
\hline INMA & $.977^{k k k}$ & $.874^{k / k}$ & $.945^{k k k}$ & 1 & & & & & \\
\hline CUR & $.967^{k * k}$ & $.973^{k * k}$ & $.922^{k-k}$ & $.958^{* *}$ & 1 & & & & \\
\hline INT & $.922^{\text {k* }}$ & $.942^{k *}$ & $.937^{\text {kk }}$ & $.912^{\text {कk }}$ & $.942^{\text {k* }}$ & 1 & & & \\
\hline MOT & $.950^{k-k}$ & $.972^{k-k}$ & $.957^{\text {kk }}$ & $.945^{\text {kक }}$ & $.921^{\text {k* }}$ & $.985^{k-k}$ & 1 & & \\
\hline EFF & $.965^{\text {kk }}$ & $.969^{k k}$ & $.975^{\text {kk }}$ & $.997^{k k k}$ & $.905^{\text {क* }}$ & $.988^{\text {k* }}$ & $.990^{k-k}$ & 1 & \\
\hline SOSK & $.931^{k * k}$ & $.984^{k-k}$ & $.970^{k * k}$ & $.912^{\text {*k }}$ & $.948^{k k}$ & $.946^{k k k}$ & $.943^{k k}$ & $.972^{k * k}$ & 1 \\
\hline
\end{tabular}

$* *$ correlation is significant at the level (2-tailed), $\mathrm{N}=223, \mathrm{Sig}$.(2-tailed) $=0.000$

It is clear trom the results of l'able ( $/$ ) that there is a correlation between internal marketing (INMA) and sott skills (SUSK), and it has been described as a positive direct relationship of (.912**) in addition to that the value of sig is less than (0.05), that is, the hypothesis is accepted The first president, who means that caring for soft skills through attention to internal marketing activities. Three sub-hypotheses are branched from this hypothesis:

A- First sub hypothesis: There is a significant correlation between INCO and SOSK soft skills.

It is clear from the results of Table (7) that there is a correlation between internal communication (INCO) and soft skills (SOSK), and it has been described as a positive direct relationship of (931**), in addition to that the value of sig is less than (0.05), as these results indicate the validity of the first sub hypothesis Also, the correlative strength of the customer response dimension (CUR) was equal to $(967 * *)$, and after the intelligence (INT) amounted to (.922 **), and for the motive dimension (MOT) reached (950**), and for the efficiency dimension (EFF) It reached $965 * *)$ ), knowing that all of them are under a level of significance less than (0.05), that is, the first sub hypothesis which means that interest in soft skills is accepted through attention to the internal contacts of the researched banks.

B - The second sub-hypothesis: There is a significant correlation between TR (Training) and Soft Skills (SOSK).

It is clear from the results of Table (7) that there is a correlation between training (TR) and soft skills (SOSK) and has been described as a positive direct relationship of $\left.984^{* *}\right)$. In addition, the value of sig is less than (0.05), as these results indicate the validity of the second sub-hypothesis, as it turned out The correlative strength of the customer response dimension (CUR) is equal to $(.973 * *)$, the dimension of intelligence (INT) is $(.942 * *)$, the motivation dimension (MOT) is (.972**), and for the efficiency dimension (EFF) is $969 . * *)$ ), knowing that all of them are under a level of significance less than (0.05), i.e. the second sub-hypothesis which means that interest in soft skills through interest in training workers for the research banks is accepted.

C- Third Sub-Hypothesis: There is a significant correlation between market share (IMSE) and soft skills (SOSK).

It is clear from the results of Table (7) that there is a correlation between market share (IMSE) and soft skills (SOSK) and has been described as a positive positive relationship of $970 * *)$. It was found that the relational power of the customer response dimension (CUR) was equal to (.922**), and the dimension of intelligence (INT) amounted to (.937 **), and the motive dimension (MOT) was $\left(.957^{* *}\right)$, and for the efficiency dimension (EFF) was. ( $\left.975^{* *}\right)$, knowing that all of them are under a level of significance less than (0.05), i.e. the second sub-hypothesis which means that interest in soft skills through interest in the labor market and the competencies available in it is accepted.

The second main hypothesis: which states (there is a significant correlation between soft skills (SOSK) and customer satisfaction (CUSA).

It is clear from the results of Table (8) that there is a correlation between soft skills (SOSK) and customer satisfaction (CUSA), and it has been described as a positive direct relationship of (.823**) in addition to that the value of sig is less than (0.05), that is, the hypothesis is accepted The first female president, which means customer satisfaction can be achieved by paying attention to soft skills activities. There are four sub-hypotheses from this hypothesis:

The first sub-hypothesis: There is a significant correlation between customer response (CUR) and customer satisfaction (CUSA). 
It is clear from the results of Table (8) that there is a correlation between customer response (CUR) and customer satisfaction (CUSA), and it has been described as a positive positive relationship and its value is $(.822 * *)$ in addition to that the value of sig is less than (0.05), as these results indicate the validity of the first sub hypothesis Also, the link strength of SEQ dimension was equal to $(.866 * *)$, and after loyalty (LE) amounted to $(.828 * *)$, and after market share (MAS) reached (.849 $* *)$, all of which are under Moral level is less than (0.05), meaning that the first sub-hypothesis is accepted, which means that attention is paid to customer satisfaction through the expansion of a rapid response to customer requirements by the research banks.

The second sub-hypothesis: There is a significant correlation between intelligence (INT) and customer satisfaction (CUSA.( It is clear from the results of Table (8) that there is a correlation between intelligence (INT) and customer satisfaction (CUSA), and it has been described as a positive positive relationship whose value is $(.878 * *)$ in addition to that the value of sig is less than (0.05), as these results indicate the validity of the first sub hypothesis, It was also found that the correlative strength of the quality of service dimension (SEQ) is equal to (.876**), and after the loyalty (LE) amounted to (.878 **), and after the market share (MAS) reached $\left(.856^{* *}\right)$, noting that all of them are below the level Moral less than (0.05), meaning that the second sub-hypothesis is accepted, which means that the interest in reaching customer satisfaction is through the interest of banks researched with creative and smart ideas and elements.

The third sub-hypothesis: There is a significant correlation between motives (MOT) and customer satisfaction (CUSA).

It is clear from the results of Table (8) that there is a correlative relationship between the motives (MOT) and customer satisfaction (CUSA), and it has been described as a positive positive relationship whose value is (.877**) in addition to that the value of sig is less than (0.05), as these results indicate the validity of the first sub hypothesis, It has also been shown that the associative strength of the Quality of Service (SEQ) dimension is equal to (.852**), and the loyalty dimension (LE) reached $(.804 * *)$, and after the MAS market share reached $(.915 * *)$, all of which are below the level Moral less than (0.05), meaning that the third sub-hypothesis is accepted, which means that the interest in reaching customer satisfaction is through the interest of the research banks in motivating employees and raising their morale, which is positively reflected on performance.

Fourth sub-hypothesis: There is a significant correlation between Efficiency EFF and Customer Satisfaction (CUSA).

It is clear from the results of Table (8) that there is a correlation between efficiency EFF) and customer satisfaction (CUSA), and it has been described as a positive direct relationship of (.891**) as well as the value of sig is less than (0.05), as these results indicate the validity of the first sub hypothesis, as It turns out that the associative strength of the quality of service dimension (SEQ) is equal to (.859**), and after the loyalty (LE) amounted to $\left(.819^{* *}\right)$, and after the market share (MAS) reached $(.843 * *)$, all of which are below the level of significance Less than (0.05), i.e., the third sub-hypothesis is accepted, which means that the concern for reaching customer satisfaction is through the interest of the research banks in motivating employees and raising their morale, which is positively reflected on performance.

Table (8) correlations between soft skills and customer satisfaction

\begin{tabular}{|c|c|c|c|c|c|c|c|c|c|}
\hline & CUR & INT & MOT & EFF & SOSK & SEQ & LE & MAS & CUSA \\
\hline CUR & 1 & & & & & & & & \\
\hline INT & $.976^{\text {k*k }}$ & 1 & & & & & & & \\
\hline MOT & $.922^{\text {k*k }}$ & $.878^{\text {k* }}$ & 1 & & & & & & \\
\hline EFF & $.810^{\text {k*k }}$ & $.893^{\text {kै }}$ & $.870^{\text {kik }}$ & 1 & & & & & \\
\hline SOSK & $.976^{\text {k-k }}$ & $.965^{\text {k* }}$ & $.917^{\text {kik }}$ & $.858^{\text {k/k }}$ & 1 & & & & \\
\hline SEQ & $.866^{\text {ktk }}$ & $.876^{\text {k* }}$ & $.852^{\text {k* }}$ & $.859^{\text {kk }}$ & $.738^{* *}$ & 1 & & & \\
\hline LE & $.828^{\text {ktk }}$ & $.878^{*}$ & $.804^{k-k}$ & $.819^{* *}$ & $.906^{\text {t* }}$ & $.929^{k-k}$ & 1 & & \\
\hline MAS & $.849^{\text {k*k }}$ & $.856^{\text {kै }}$ & $.915^{\text {k-k }}$ & $.843^{\text {k*k }}$ & $.845^{\text {kक }}$ & $.832^{k-k}$ & $.849^{k-k}$ & 1 & \\
\hline CUSA & $.822^{\text {k*k }}$ & $.878^{k *}$ & $.877^{\text {kंk }}$ & $.891^{\text {k* }}$ & $.823^{* *}$ & $.807^{k * k}$ & $.822^{\text {k*k }}$ & $.878^{k * k}$ & 1 \\
\hline
\end{tabular}

$* *$ correlation is significant at the level (2-tailed), $\mathrm{N}=223$, Sig.(2-tailed) $=0.000$

\section{2-The hypothesis of impact}

The third main hypothesis: which states (there is a statistically significant effect of internal marketing (INMA) on customer satisfaction (CUSA).

To test this hypothesis, the researcher built a model of the structural modeling equation that explains the relationship between internal marketing dimensions (INMA) and customer satisfaction dimensions (CUSA), and Figure (2) shows the effect of 
internal marketing dimensions on removing customer satisfaction, and by interpreting the results it is clear that the model matches the criteria Match quality.

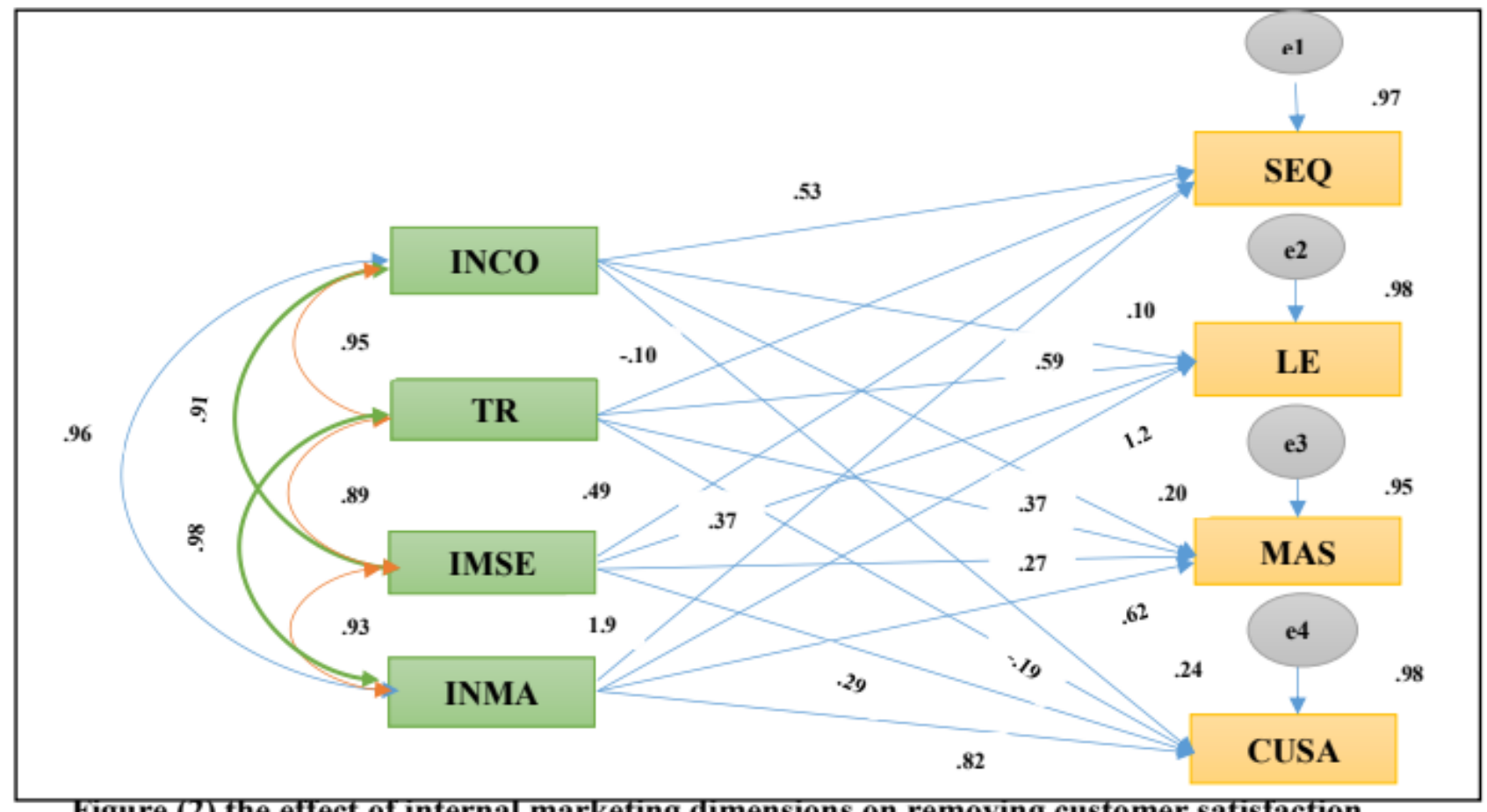

Figure (2) the effect of internal marketing dimensions on removing customer satisfaction

As it becomes clear from the interpretation of the results of Table (9) and shown in Figure (2), the validity of the hypothesis of the effect of internal marketing (INMA) on customer satisfaction (CUSA), as there is a positive effect of internal marketing on customer satisfaction, as the increase in internal marketing by one unit It leads to an increase in customer satisfaction by (.825), a standard error (.079), and a critical ratio (10.44)

As for the effect relationship between internal marketing (INMA) on the dimensions of customer satisfaction (CUSA), it represents a significant relationship, as the increase in internal marketing by one unit leads to an increase after the quality of service (SEQ) by (1.944) and a standard error (.105), and the ratio Critical (18.51). While increasing internal marketing by one unit leads to an increase after loyalty (LE) by (1.241) and a standard error (. 123), and a critical ratio (10.089). An increase in internal marketing by one unit leads to an increase after market share (MAS) with a value of (. 622) and a standard error (. 117), and a critical ratio (5.316). Based on the foregoing proves the validity of the second main hypothesis, and three sub-hypotheses are derived from this hypothesis. :

A- The first sub-hypothesis: which states (there is a statistically significant effect relationship for internal communications (INCO) in the dimensions and customer satisfaction (CUSA)

The results of Table (9) shown in Figure (2) show a significant effect of the internal communication dimension (INCO) on customer satisfaction (CUSA), as there was a positive effect of internal communications (INCO) on the quality of service (SEQ), as the increase After internal communications by one unit leads to an increase after the quality of service by (.537) and a standard error (.025), and a critical ratio (21.48). While the impact relationship for internal communications (INCO) in after loyalty (LE) it represents a moral relationship, as An increase after internal communications by one unit leads to an increase after loyalty by (. 104) and a standard error (.034), and a critical ratio (3.058). It turns out that the effect of internal communications (INCO) after the market share (MAS) is that it represents a significant relationship, as an increase after the internal communications by one unit leads to an increase after the market share by (.208) and a standard error (.012), and a critical ratio ( 17.33)

B- The second sub-hypothesis: which states (there is a relationship of significant significance for training (TR) in the dimensions and customer satisfaction (CUSA).

The results of Table (9), shown in Figure (2), show the presence of a reverse effect of the TR dimension on customer satisfaction (CUSA) and its amount (.198), a standard error (.034), and a critical ratio (-5.823). Negative training (TR) in after quality of service (SEQ), as an increase after training by one unit leads to a decrease in after quality of service by (-. 010) and a standard error (054), and a critical ratio (-0.185). In after loyalty (LE) it represents a significant relationship, so an 
increase after training by one unit leads to an increase after loyalty by (.591) and a standard error (.042), and a critical ratio (24.65). It was found that the effect of training effect (TR) on the after market share (MAS) is that it represents a significant relationship, as an increase after the internal communications by one unit leads to an increase after the market share by (.378) and a standard error (.031), and a critical ratio (12.19).

C- The third sub-hypothesis: which states (there is a statistically significant effect relationship for internal market research (IMSE) in the dimensions and customer satisfaction (CUSA).

The results of Table (9) shown in Figure (2) show a significant effect of the internal market research dimension (IMSE) on customer satisfaction (CUSA), as there was a positive effect of internal market research (IMSE) on the quality of service (SEQ), as An increase after internal market research by one unit leads to an increase in after-service quality by (.495) and a standard error (.023), and a critical ratio (21.52). While the impact of internal market research (IMSE) in after loyalty (LE) it represents a significant relationship, As an increase after internal market research by one unit leads to an increase after loyalty by (.317) and a standard error (.043), and a critical ratio (7.372). It was found that the effect of the internal market research (IMSE) after the market share (MAS) is that it represents a significant relationship, as an increase after the internal market research by one unit leads to an increase after the market share by (270) and by a standard line (.035), and the ratio Critical (7.714).

Table (9) Results of an impact analysis of the dimensions of the internal marketing variable in the dimensions of the customer satisfaction variable

\begin{tabular}{|c|c|c|c|c|c|c|c|c|}
\hline \multicolumn{3}{|c|}{$\begin{array}{l}\text { Regression path } \\
\text { (direct) }\end{array}$} & $\begin{array}{l}\text { Standard } \\
\text { estimates }\end{array}$ & $\begin{array}{l}\text { Standard } \\
\text { error }\end{array}$ & $\begin{array}{l}\text { The } \\
\text { critical }\end{array}$ & $\begin{array}{c}\text { Values } \\
\text { R2 }\end{array}$ & $\begin{array}{l}\text { Probability } \\
\text { (P) }\end{array}$ & Effect type \\
\hline SEQ & 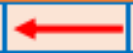 & INCO & .537 & .025 & 21.48 & \multirow{4}{*}{.971} & *** & moral \\
\hline SEQ & 4 & TR & -.010 & .054 & -0.185 & & N.S & Immoral \\
\hline SEQ & $\longleftarrow$ & IMSE & .495 & .023 & 21.52 & & $* * *$ & moral \\
\hline SEQ & $\longleftarrow$ & INMA & 1.944 & .105 & 18.51 & & $* * *$ & moral \\
\hline LE & $\leftarrow$ & INCO & .104 & .034 & 3.058 & \multirow{4}{*}{.983} & $* * *$ & moral \\
\hline LE & $\leftarrow$ & TR & .591 & .042 & 24.65 & & $* * *$ & moral \\
\hline LE & $\longleftrightarrow$ & IMSE & .317 & .043 & 7.372 & & $* * *$ & moral \\
\hline LE & $\longleftarrow$ & INMA & 1.241 & .123 & 10.089 & & $* * *$ & moral \\
\hline MAS & 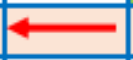 & INCO & .208 & .012 & 17.33 & \multirow{4}{*}{.956} & *** & moral \\
\hline MAS & 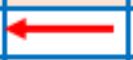 & TR & .378 & .031 & 12.19 & & $* * *$ & moral \\
\hline MAS & $\leftarrow$ & IMSE & .270 & .035 & 7.714 & & $* * *$ & moral \\
\hline MAS & $\longleftarrow$ & INMA & .622 & .117 & 5.316 & & $* * *$ & moral \\
\hline CUSA & $\longleftarrow$ & INCO & .247 & .023 & 10.739 & \multirow{4}{*}{.987} & $* * *$ & moral \\
\hline CUSA & $\longleftarrow$ & TR & -.198 & .034 & -5.823 & & N.S & Immoral \\
\hline CUSA & $\longleftarrow$ & IMSE & .290 & .047 & 6.170 & & $* * *$ & moral \\
\hline CUSA & $\longleftarrow$ & INMA & .825 & .079 & 10.44 & & $* * *$ & mora \\
\hline
\end{tabular}

The fourth main hypothesis: which states (there is an interactive effect of soft skills with internal marketing to influence customer satisfaction).

The interaction of soft skills with internal marketing leads to the enhancement of the effect of internal marketing on customer satisfaction. Therefore, in order to reveal the relationship of the interactive effect between the soft skills variable and the dimensions of internal marketing, interactions with the elements involved in the analysis must be made, the variables included in the analysis were coded by giving them codes to indicate them, The interaction of internal marketing for internal marketing (INM) with soft skills (SOSK) with the symbol (SINM), the interaction of comprehensive marketing training (TR) with soft skills (SOSK) with the symbol (SRT), and the interaction of internal market research for comprehensive marketing (IMS) With soft skills (SOSK) symbol (SIMS), as shown in Figure (3).

Three sub-hypotheses are branched from this hypothesis: 
The first sub-hypothesis: This hypothesis states that (there is an interaction effect of soft skills with internal communications for internal marketing (SINM) to influence the dimensions of customer satisfaction).

The results of Table (10) shown in Figure (3) show an interaction effect of soft skills with internal communications for internal marketing (SINC) in after service quality (SEQ), as increasing the interaction of soft skills with internal communications by one standard weight leads To increase after the quality of service by (.767) and a standard error (.008), and a critical ratio $(95,875)$. Increasing the interaction of soft skills with internal communications by one standard weight leads to an increase after loyalty by (.098) and a standard error (.008), and a critical ratio (12.25). While increasing the interaction of soft skills with internal communications by one standard weight leads to Increase after the market share by (.308) and by a standard error (.010), and by a critical percentage $(.30 .8($

From the foregoing, this indicates the papers of the first sub-hypothesis of the fourth main hypothesis of the research which states (There is a relationship of interaction of soft skills with internal communications for internal marketing (SINM) to influence the dimensions of customer satisfaction).

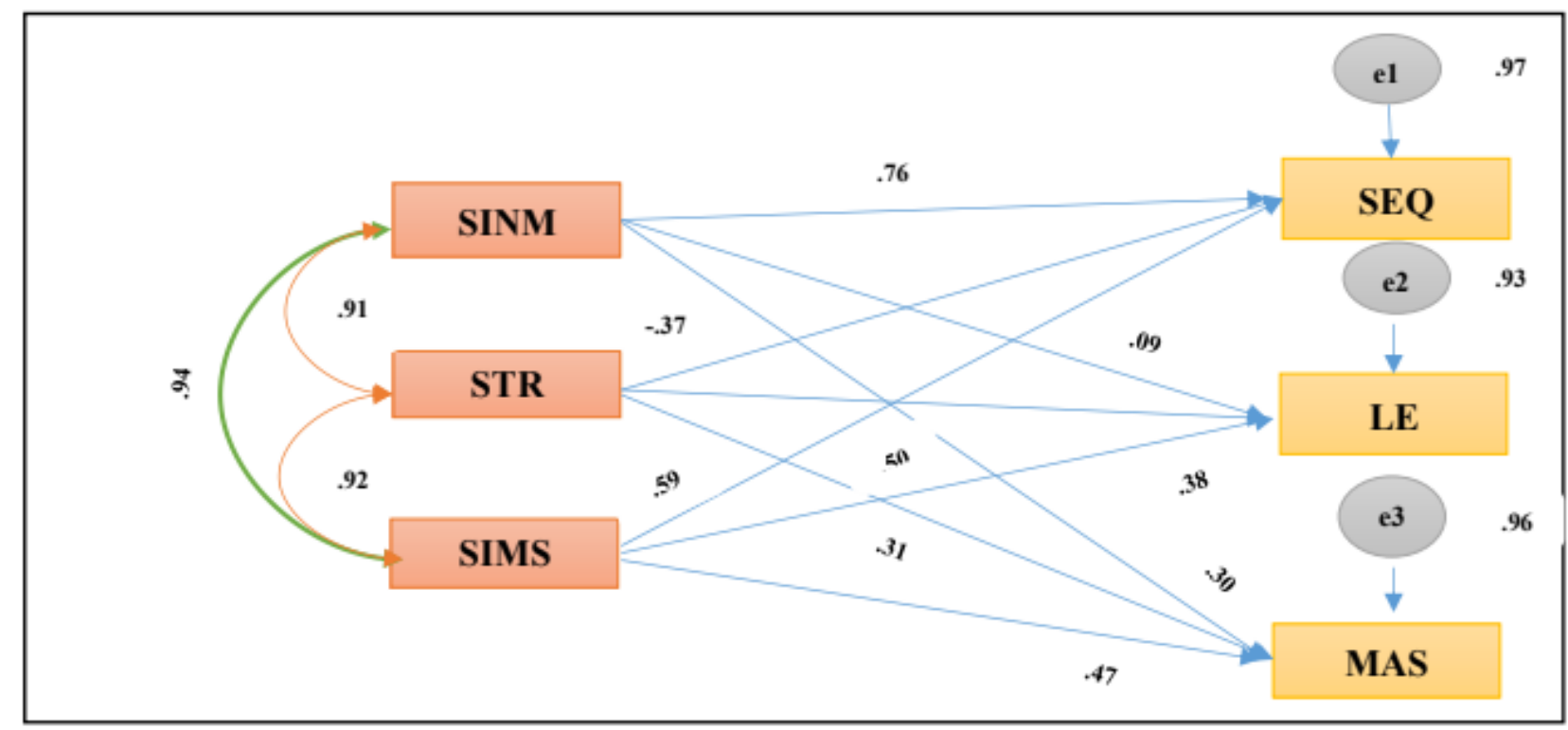

Figure (3) is the standard model for soft skills interaction with internal marketing in customer satisfaction

The second sub-hypothesis: This hypothesis states that (there is an interactive effect relationship of soft skills with training for internal marketing (STR) to influence the dimensions of customer satisfaction(

The results of Table (10), shown in Figure (3), show an interaction effect of soft skills with training for internal marketing (STR) in the dimension of service quality (SEQ), as increasing the interaction of soft skills after training with a single standard weight leads to an increase After the quality, the service increased by (.313), with a standard error (.008), and a critical ratio (41.55). And the increase in the interaction of soft skills with training by one standard weight leads to an increase after loyalty by (.508) and a standard error (.0010), and a critical ratio (50.8), while an increase in the interaction of soft skills with training by one standard weight leads to an increase after Market share of (.313) and standard error (.008), and a critical ratio (39.12)

From the foregoing, this indicates the papers of the second sub-hypothesis from the fourth main hypothesis of the research, which states (There is an interaction effect of soft skills with training for internal marketing (STR) to influence the dimensions of customer satisfaction

The third sub-hypothesis: This hypothesis states that (there is an interactive effect relationship for soft skills with internal market research for internal marketing (SINS) to influence the dimensions of customer satisfaction)

The results of Table (10), shown in Figure (3), show an interaction effect of soft skills with internal market research for internal marketing (SIMS) in after service quality (SEQ), as increasing the interaction of soft skills with training by one standard weight leads To increase after the quality of service by (.594) and a standard error (.008), and a critical ratio (39.12). And the increase in the interaction of soft skills with internal market research by one standard weight leads to an increase after loyalty by (.388) and a standard error (.008), and a critical ratio (43.11). While an adverse reaction came with the internal market research in the market share, as any Increased interaction after soft skills with internal market research by one 
standard weight leads to a decrease after the market share by (.374) and a standard error (.009), and a critical percentage (41.55).

From the foregoing, this indicates the papers of the third sub-hypothesis of the fourth main hypothesis for research, which states (There is a relationship of interaction of soft skills with internal market research for internal marketing (STR) to influence the dimensions of customer satisfaction).

Table (10) Results of the analysis of the interactive impact of the soft skills variable with internal marketing in customer satisfaction

\begin{tabular}{|c|c|c|c|c|c|c|c|c|}
\hline \multicolumn{3}{|c|}{$\begin{array}{l}\text { Regression path } \\
\text { (indirect) }\end{array}$} & $\begin{array}{l}\text { Standard } \\
\text { estimates }\end{array}$ & $\begin{array}{c}\text { Standard } \\
\text { error }\end{array}$ & $\begin{array}{l}\text { The } \\
\text { critical }\end{array}$ & $\begin{array}{c}\text { Values } \\
\text { R2 }\end{array}$ & $\begin{array}{l}\text { Probability } \\
\text { (P) }\end{array}$ & Effect type \\
\hline SEQ & $4--4$ & SINC & .767 & .008 & 95.875 & \multirow{3}{*}{.97} & **** & moral \\
\hline SEQ & 4-ー- & STR & .313 & .008 & 39.12 & & **** & moral \\
\hline SEQ & $4--4$ & SIMS & .594 & .008 & 74.25 & & $* * *$ & moral \\
\hline LE & 4-ー- & SINC & .098 & .008 & 12.25 & \multirow{3}{*}{.93} & **** & moral \\
\hline LE & 4--A & STR & .508 & .010 & 50.8 & & **** & moral \\
\hline LE & $4--4$ & SIMS & .388 & .008 & 43.11 & & **** & moral \\
\hline MAS & $4--1$ & SINC & .308 & .010 & 30.8 & \multirow{3}{*}{.96} & $* * *$ & moral \\
\hline MAS & イーーー & STR & -.374 & .009 & -41.55 & & N.S & Immoral \\
\hline MAS & ४ー-ー & SIMS & .470 & .009 & 52.22 & & $* * *$ & moral \\
\hline
\end{tabular}

3-Summary of direct and indirect (interactive) effect of research variables.

The results shown in Table (11) indicate that most of the results of the interactive analysis were accepted while the interaction of soft skills with internal market research was not encouraged for the effect, since the direct effect between them is higher than the interactive effect, and therefore the sub-hypothesis of the interactive effect between these two is rejected. The two variables. As shown in the table (11).

Table ((11) Summary of direct and indirect (interactive) effect ofresearch variables

\begin{tabular}{|c|c|c|c|c|c|c|c|c|c|}
\hline \multicolumn{3}{|c|}{$\begin{array}{l}\text { Regression path } \\
\text { (indirect) }\end{array}$} & $\begin{array}{l}\text { Standard } \\
\text { estimates }\end{array}$ & $\begin{array}{l}\text { Standar } \\
\text { d error }\end{array}$ & \multicolumn{3}{|c|}{$\begin{array}{c}\text { Regression path } \\
\text { (direct) }\end{array}$} & $\begin{array}{l}\text { Standard } \\
\text { estimates }\end{array}$ & $\begin{array}{l}\text { Standar } \\
\text { d error }\end{array}$ \\
\hline SEQ & $4---$ & SINC & .767 & .008 & SEQ & & SINC & $\mathbf{. 5 3 7}$ & .025 \\
\hline SEQ & 1--U & STR & .313 & .008 & SEQ & & STR & -.010 & .054 \\
\hline SEQ & 4--- & SIMS & .594 & .008 & SEQ & & SIMS & .495 & .023 \\
\hline LE & 4--- & SINC & .098 & .008 & LE & & SINC & .104 & .034 \\
\hline LE & 4--- & STR & .508 & .010 & LE & & STR & .591 & .042 \\
\hline LE & 4--A & SIMS & .388 & .008 & LE & $\leftarrow$ & SIMS & .317 & .043 \\
\hline MAS & 1--- & SINC & .308 & .010 & MAS & & SINC & .208 & .012 \\
\hline MAS & 4ー-U & STR & -.374 & .009 & MAS & & STR & .378 & .031 \\
\hline MAS & ムーー- & SIMS & .470 & .009 & MAS & $\longleftarrow$ & SIMS & .270 & .035 \\
\hline
\end{tabular}

\section{THE FOURTH TOPIC: CONCLUSIONS AND RECOMMENDATIONS}

\section{First: the conclusions}

Based on the researcher's findings of practical results of the research variables: A set of recommendations has been formulated, namely:

1- It was found from the results of the research that there are significant correlation relationships between internal marketing and its dimensions, soft skills and its dimensions, and this confirms that the research banks are interested in the three internal marketing activities (internal communications, training, internal market research) which will lead to the result in reaching customer satisfaction 
2- $\quad$.It was found from the results of the research that there are significant correlation relationships between soft skills and its dimensions, customer satisfaction and its dimensions, and this confirms that the research banks are concerned with the effectiveness of soft skills (customer response, intelligence, motivation research, efficiency) which will lead to the result in achieving customer satisfaction.

3- The results of the research show that there are statistical impact relationships between internal marketing and its dimensions, customer satisfaction and its dimensions, and this confirms that the research banks are interested in the three internal marketing activities (internal communications, training, internal market research) which will lead to the result in reaching the customer's satisfaction.

4- $\quad$ It was found from the research results that there are statistical effects relationships between the interaction of soft skills with internal marketing and its dimensions in customer satisfaction, and this confirms that the research banks are interested in the inclusion and interaction of the capabilities and skills of workers in the three internal marketing activities (internal communications, training, internal market research) which will lead to the result To reach customer satisfaction.

5- The results of the analysis confirm that the managers and employees of the research banks prevail among them the spirit of cooperation and work as a team, and this in turn reflects positively on the performance of the company and as a result the customer's satisfaction.

6- $\quad$ The results of the research indicate that the managers and employees of the researched banks have the capabilities, skills and ability to assume responsibility in addition to their current jobs, and this explains that the researched banks have a competitive advantage compared to the competing banks.

7- $\quad$ The results showed that the top management of the research banks is interested in taking opinions, proposals and ideas from the middle and lower departments and allowing them to participate in making decisions that ultimately affect the performance

of the bank.

\section{Second: Recommendations}

1- The necessity of enhancing internal marketing activities through a set of means, which are continuous development, self-capabilities, and continuing education.

2- $\quad$ Providing employees of banks that are searching with training and development programs so that they can keep abreast of technological developments and changes taking place in the field of banking industries.

3- $\quad$ Providing managers and employees with internal and external training courses to increase their knowledge of models of internal marketing activities, so that banks can involve the internal and the trained parties when developing and formulating these activities.

4- $\quad$ Providing effective means of communication, whether between the employees (horizontal communications), or between the higher management and the rest of the company's departments (vertical communications) so that they can transfer ideas and information as quickly as possible.

5- $\quad$ Establishing a network of alliances with internal and external stakeholders (employees, customers) to benefit from external opinions and proposals when providing the service.

\section{Sources and references}

1- Abzari, M., Ghorbani, H., and Madani, F.A. (2011). "The Effect of Internal Marketing on Organizational Commitment from Market-Orientation Viewpoint in Hotel Industry in Iran”, International Journal of Marketing Studies, Vol. 3, No. 1, pp. 147-155.

2- $\quad$ Agyei ,Paul, Mensah.,\&Kilika, James, M.,( (2013), “The Relationship Between Service Quality and Customer Loyalty in the Kenyan Mobile Telecommunication Service Industry”, European Journal Of Business And Management, Vol. 5, No. 23 ,pp26-36

3- $\quad$ Anderson, E.W., Fornell, C., \&Mazvancheryl, S.K. (2004). Customer Satisfaction and Shareholder value. Journal of Marketing, 68(4),pp 172-185

4- Beyerlein, M.M., McGee, C., Klein, G.D., Nemiro, J.E. \&Broedling, L.,2003,The Collaborative Work System Fieldbook: Strategies, Tools, and Techniques. San Francisco: Pfeiffer

5- Blessing, Gerald \& Natter, Martin(2019), Do Mystery Shoppers Really Predict Customer Satisfactionand Sales Performance, Journal of Retailing 
6- Boohene, Rosemond \& Agyapong, Gloria,(2011), "Analysis of the Antecedents of Customer Loyalty of Telecommunication Industry in Ghana: The Case of Vodafone (Ghana)",International Business Research,Vol.. 4, No. 1,pp.229-240.

7- $\quad$ Bowden, J., Hart, G., King, B., Trigwell, K. \&Watts, O. (2000). Generic capabilities of ATN University Graduates.

8- $\quad$ Chebat ,Jean-Charles \& Slusarczyk.Witold(2005),How emotions mediate the effects of perceived justice on loyalty in service recovery situations: an empirical study,Journal of Business Research, 2005, vol. 58, issue 5, 664-673.

9- Chicu ,Dorina \& Maria del Mar Pàmies\&Gerard Ryan and Christine Cross(2019), Exploring the influence of the human factor oncustomer satisfaction in call centres, RQ Business Research Quarterly

10- Christopher, D. and Tanwar, A. (2012), "Knowledge management in outsourcing environment: people empowering people", The IUP Journal of Knowledge Management, Vol. X, No. 2, pp. 61-86.

11- Emaluta ,Fikriya, Isnalita, and NoorlailieSoewarno.(2019). The Effect of Customer Relationship Management (CRM) To Customers' Loyalty and Customers' Satisfaction as Mediator Variables. JURNAL AKSI (AkuntansidanSistemInformasi), Vol. 4(2). http://doi.org/10.32486/aksi.v4i2.352

12- $\quad$-Farouk, A. \&Khlel, E. Mohamed, G. 2010, " Impact of Internal Marketing on the Service Quality in Sport Clubs", World Journal of Sport Sciences 3 (S), pp. 1196-1202

13- Foss,Nicolai J\&Snejina, Michailova and Kenneth Husted(2010),Governing Knowledge Sharing in Organizations: Levels of Analysis, Governance Mechanisms, and Research Directions, Journal of Management Studies 47(3):455-482

14- Friberg, Erik, 2015, a holistic view of marketing communication of accessories, Faculty of Engineering, LTH Department of Production management, Copyright (C Erik Friberg Lund, Sweden

15- Griese M, Haug M, Brasch F, Freihorst A, Lohse P, et al. (2009) Incidence and classification of pediatric diffuse parenchymal lung diseases in Germany. Orphanet J Rare Dis 4: 26 10.1186/1750-1172.

16- Huang, Yu-Ting\& Thiele, Sharyn(2014), The moderating effect of cultural congruence on the internal marketing practice and employee satisfaction relationship: An empirical examination of Australian and Taiwanese born tourism employees, Tourism Management 42 ,pp 196-206.

17- Kadic-Maglajlic, Selma\& Nathaniel Boso and Milena Micevskic(2017), How internal marketing drive customer satisfaction in matured and maturing European markets, Journal of Business Research, Vol. 1, No. 2, pp1 - 9.

18- Khedkar. (2015). Effect Of Customer Relationship Management On Customer Satisfaction And Loyalty International Journal Of ManagementVolume 6, Issue 5, pp. 01-07

19- Kotler, Philip KevinKeller. (2000) Framework for Marketing Management\& Custom case.3rdEdition. New Jersey: Prentice Hall

20- Kotler, Philip KevinKeller. (2006). Framework for Marketing Management\& Custom case.3rdEdition. New Jersey: Prentice Hall

21- Levasseur,Robert E(2013),People Skills: Developing Soft Skills-A Change Management Perspective,Journal of Language and Communication, 43(6):566-571.

22- Liew, J., McTigue, E., Barrois, L. \& Hughes, J. N. (2008). Adaptive and effortful control and academic self-efficacy beliefs on literacy and math achievement: A longitudinal study on 1st through 3rd graders. Early Childhood Research Quarterly, 23, 515-526

23- Linell, P. (2009), Approaching dialogue: Talk, interaction and contexts in dialogical perspectives. Philadelphia: J. Benjamins Publishing Company

24- Lombard, M.R. 2010, "Employees as customers - An Internal Marketing Study of the Avis Car Rental group in South Africa", African Journal of Business Management Vol. 4(4), pp. 362-372.

25- Lupiyoadi, Rambat, danHamdani, A. 2008. ManajemenPemasaranJasa. Jakarta: SalembaEmpat

26- Moore, A.W., Jan, L.Y., Jan, Y.N. (2002). hamlet, a binary genetic switch between single-and multiple- dendrite neuron morphology. Science 297(5585): 1355-1358.

27- Munir, Z.A., Othman, A.A., Shukur, S.A.M., Ithnin, R., and Rusdi, S. D. (2015). "Practices of Internal Marketing in Small and Medium Industry" International Journal of Social Science and Humanity, Vol. 5, No. 4, pp. 358-361

28- Mytzek, Ralf ,Bullinger, Hans-Jörg; Zeller, Beate.( 2004). Soft Skills. ÜberfachlicheQualifikationenfürbetrieblicheArbeitsprozesse. Bielefeld: W. Bertelsmann Verlag.

29- Nonaka, I., \& von Krogh, G. (2009). Tacit knowledge and knowledge conversion: Controversy and advancement in organizational knowledge creation theory. Organization Science, 20(3), 635-652 
30- Papasolomou, I., and Vrontis, D. (2006). "Using Internal Marketing to Ignite the Corporate Brand: The Case of the UK Retail Bank Industry”, Brand Management, Vol. 14, No. 1/2, pp.177-195.

31- Proctor, T. (2010). "Internal Marketing and Its Basis for Sound Customer Relationship Management", Journal of Management and Marketing in Healthcare, Vol. 3, No. 4, pp. 256- 263.

32- Rafiq, M., and Ahmad, P.K. (2000). “Advances in Internal Marketing: Definition, Synthesis and Extension”, Journal of Services Marketing, Vol. 14, No. 6, pp. 449-462

33- Rasmani., Widodo, J., \&Wibowo. (2017). A model for developing soft skill training management oriented towad service quality for SHS couselors. The Jornal of Educational Development, 5(1), 39-49.

34- Riggio,R,Gomez,k,Goratti,L,Fedrizzi(2014),V-cell:going beyond the call abstraction in 5G mobile networke,operationmamagment, ppl-5.

35- Robbins, S. P. \& Coulter, M. (2005). Management (8th ed.). Englewood Cliffs, NJ: Prentice Hall.

36- Sain, S. \& Wilde, S. (2014). Customer Knowledge Management: Leveraging Soft Skills to Improve Customer Focus. Berlin: Springer

37- Saravanan,R\&Rao,K(2007), The impact of total quality service age on quality and operational performance: An empirical study, The TQM Magazine 19(3):197-205.

38- Schulz, B. (2008). The Importance of soft skills: education beyond academic knowledge. Journal of Language and Communication, (June), 146-154.

39- Senapathi,Natarajan Kannan(2011),Green Synthesis of Silver Nanoparticles using Bacillus subtillus IA751 and its Antimicrobial Activity, $\quad$ Research Journal of Nanoscience and Nanotechnology,Volume: 1 | Issue: 2 | Page No.: 87-94.

40- Souca, M.L. (2014), "Customer dissatisfaction and delight: completely different concepts, or part of a satisfaction continuum?”, Management \& Marketing. Challenges for the Knowledge Society, Vol. 9, No. 1, pp. 75-90.

41- Stewart, C. L.; Boyle, L. A.; O’Connell, N. E., 2016. The effect of increasing dietary fibre and the provision of straw racks on the welfare of sows housed in small static groups. Anim. Welfare, 20 (4): 633-644.

42- Tasmia, EkramTushi, 2014, Holistic Service Marketing, Strategies and Corporate, Global Journal of Management and Business, Volume 14 Issue 1 Version 1.0 Year

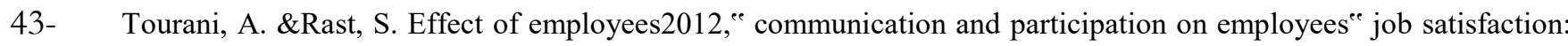
An empirical study on airline companies in Iran. In 2nd International Conference on Economics, Trade and Development (vol. 36).

44- Tulgan, Bruce(2015),Bridging the Soft Skills Gap: How to Teach the Missing Basics to Todays Young Talent, NJ: John Wiley \& Sons, Inc.

Volume 22, Issue 2, , Pages 83-95.

Volume 95, I 3, , pp 47-62

45- Yu-Ting Huang Sharyn Rundle-Thiele , (2015),"A holistic management tool for measuring internal marketing activities",Journal of Services Marketing, Vol. 29 Iss 6/7 pp1-34

46- Zakaria, Ahmad, 2014, The Impact of customer relationship n customer satisfaction in the banking industry, Journal of Business and management, Vol.6, No.32,pp. 99-112 10 